\title{
Solid State Fermentation of a Raw Starch Digesting Alkaline Alpha-Amylase from Bacillus licheniformis RT7PE1 and Its Characteristics
}

\author{
Romana Tabassum, ${ }^{1}$ Shazia Khaliq, ${ }^{1}$ Muhammad Ibrahim Rajoka, ${ }^{2}$ and Foster Agblevor ${ }^{3}$ \\ ${ }^{1}$ National Institute for Biotechnology and Genetic Engineering (NIBGE), P.O. Box 577, Faisalabad, Pakistan \\ ${ }^{2}$ Department of Bioinformatics, G C University, Faisalabad, Pakistan \\ ${ }^{3}$ Biological Engineering Department, Utah State University, 4105 Old Main Hill, Logan, UT 84322-4105, USA
}

Correspondence should be addressed to Romana Tabassum; romanatabassum@yahoo.com

Received 30 August 2013; Revised 25 November 2013; Accepted 26 November 2013; Published 21 January 2014

Academic Editor: Goetz Laible

Copyright (C) 2014 Romana Tabassum et al. This is an open access article distributed under the Creative Commons Attribution License, which permits unrestricted use, distribution, and reproduction in any medium, provided the original work is properly cited.

\begin{abstract}
The thermodynamic and kinetic properties of solids state raw starch digesting alpha amylase from newly isolated Bacillus licheniformis RT7PE1 strain were studied. The kinetic values $Q_{p}, Y_{p / s}, Y_{p / X}$, and $q_{p}$ were proved to be best with $15 \%$ wheat bran. The molecular weight of purified enzyme was $112 \mathrm{kDa}$. The apparent $K_{m}$ and $V_{\max }$ values for starch were $3.4 \mathrm{mg} \mathrm{mL}^{-1}$ and $19.5 \mathrm{IU} \mathrm{mg}^{-1}$ protein, respectively. The optimum temperature and $\mathrm{pH}$ for $\alpha$-amylase were $55^{\circ} \mathrm{C}$, 9.8. The half-life of enzyme at $95^{\circ} \mathrm{C}$ was $17 \mathrm{~h}$. The activation and denaturation activation energies were 45.2 and $41.2 \mathrm{~kJ} \mathrm{~mol}^{-1}$, respectively. Both enthalpies $\left(\Delta H^{*}\right)$ and entropies of activation $\left(\Delta S^{*}\right)$ for denaturation of $\alpha$-amylase were lower than those reported for other thermostable $\alpha$-amylases.
\end{abstract}

\section{Introduction}

Starch is an excellent carbon source in nature and major storage product of many economically important crops. A large-scale starch processing industry has emerged in the last century [1]. Five groups of enzymes play a key role in the hydrolysis of starch. These enzymes comprise about 30\% of the world's enzyme production. Alpha amylases (endo-1,4a-D-glucan glucanohydrolase, E.C.3.2.1.1) are extracellular endo enzymes that randomly cleave the 1,4-a linkage between adjacent glucose units in the linear amylose chain and ultimately generate glucose, maltose, and maltotriose units [2]. Alpha amylases derived from microbial sources have great success and replaced the chemical hydrolysis of starch in starch processing industries. Alpha amylases have a number of applications, including liquefaction of starch in the alcohol, brewing, and sugar industries and in the textile industry for desizing of fabrics [3]. They also have applications in laundry and detergents or as antisalting agents and baking such as bread making [3], since thermostability and alkaline characteristics are important features for industrial applications of amylase isolated from alkalophilic organisms [4].
The microbial $\alpha$-amylases for industrial processes are derived mainly from Bacillus subtilis, Bacillus amyloliquefaciens, and Bacillus licheniformis asthey are capable of secreting amylases into the culture supernatant in submerged [5]. The microbial production of alpha-amylase is greatly influenced by the composition of the medium culture and environmental and growth kinetic parameters [5]. However, solid state fermentation provides an interesting alternative for concentrated enzyme production and less purification costs [6]. This work reports the solid state production, kinetic and thermodynamic properties of raw starch-digesting alkaline alpha-amylase from an indigenous culture of $B$. licheniformis RTPE1 which possessed potentially interesting properties from $\alpha$-amylases already described.

\section{Materials and Methods}

2.1. Microorganism and Production Medium. Indigenous Bacillus licheniformis RTPE-1strain was maintained in NIBGE stock culture collection and 16S rRNA accession number EF644418 submitted at NCBI. The Bacillus 
licheniformis RTPE1 was maintained on maize starch $(1 \% \mathrm{~W} / \mathrm{V})$ plates containing basal salts medium and $2.5 \%$ agar. The basal salt medium comprised of $\left(\mathrm{g} / \mathrm{L}^{-1}\right) \mathrm{K}_{2} \mathrm{HPO}_{4}$ 1.0, $\left(\mathrm{NH}_{4}\right)_{2} \mathrm{PO}_{4} 1.0, \mathrm{MgCl}_{2} \quad 0.5$, yeast extract 10.0 , and maize starch 10 . For liquid media preparation, all the media components were added and mixed one by one in one liter conical flask containing $200 \mathrm{~mL}$ distilled water. The $\mathrm{pH}$ of the medium was adjusted to 7.0 with $1 \mathrm{~N} \mathrm{HCl} / \mathrm{NaOH}$. The medium was autoclaved at 20 p.s.i, $120^{\circ} \mathrm{C}$ for $20 \mathrm{~min}$.

2.2. Preparation of Inoculums. The basal salt medium containing maize starch $(1 \% \mathrm{~W} / \mathrm{V})$ was dispensed in $50 \mathrm{~mL}$ quantity into $250 \mathrm{~mL}$ Erlenmeyer flasks. A single colony from fresh agar culture plate was transferred into the above medium and incubated at $37^{\circ} \mathrm{C}$ for $24 \mathrm{~h}$ on an orbital shaker (Gallenkamp, UK, $150 \mathrm{rpm}$ ).

2.3. Growth of Organism in Solid State Fermentation (SSF). The SSF studies were carried out in one-litre Erlenmeyer flasks containing different concentrations of wheat bran, maize bran, and maize starch. Each carbon source was moistened with $25 \mathrm{~mL}$ basal salt solution. The flasks were autoclaved for $20 \mathrm{~min}$ and cooled. For time course study the flasks were inoculated with $5 \mathrm{~mL}$ of fresh inoculums ( $5 \mathrm{mg}$ cell mass $\mathrm{mL}^{-1}$ ) and incubated at $37^{\circ} \mathrm{C}$ for 7 days. The incubator was humidified by sterile water. For the extraction of extracellular $\alpha$-amylase from solid state fermentation experiments, after desired intervals $(24,48,72,96,120,144$, and $168 \mathrm{~h}$ ), the flasks were taken out in triplicate and the enzyme was extracted (three washings) with $100 \mathrm{~mL}$ of $10 \mathrm{~mol}$ phosphate buffer ( $\mathrm{pH}$ 7.0) after vigorous shaking on an orbital shaker $\left(150 \mathrm{rpm}, 4^{\circ} \mathrm{C}\right)$. The extracted enzyme was centrifuged (at $15,000 \times \mathrm{g}$ for $10 \mathrm{~min}$ at $4^{\circ} \mathrm{C}$ ) to get clear supernatant for enzyme assay. All the experiments were run in three replicates.

2.4. Assay for Alpha-Amylase Activity. The activity of $\alpha$ amylase was measured on the basis of liberated reducing sugars [7] using 3,5-dinitrosalicylic acid (DNS) using starch as the substrate after $10 \mathrm{~min}$ incubation. One unit of $\alpha$ amylase activity was defined as the amount of enzyme, which released $1 \mu \mathrm{mol}$ of maltose or glucose equivalent per min under the assay conditions. Glucose was measured using glucose oxidase kit.

2.5. Protein Determination. The protein in the enzyme preparation was quantified by the Bradford method [8] using bovine serum albumin as the standard.

2.6. Purification of $\alpha$-Amylase. All purification steps were conducted at room temperature. Enzyme extract from above $(1000 \mathrm{~mL})$ was purified by a combination of ammonium sulphate precipitation, ion-exchange, and gel filtration column chromatography as described previously [9] with 20-fold increase in specific activity (138 to $2769 \mathrm{U}\left(\mathrm{mg}^{-1}\right.$ protein) with $30 \%$ recovery).
2.7. pH Optima Studies. The effect of $\mathrm{pH}$ on the stability of $\alpha$ amylase was determined by assay of $\alpha$-amylase activity after incubating the enzyme in the reaction system of different $\mathrm{pH}$ values at $50^{\circ} \mathrm{C}$ for $1 \mathrm{~h} \mathrm{[10]}$.

2.8. Effect of Substrate Concentration. $\alpha$-Amylase was assayed in $100 \mathrm{mM}$ phosphate buffer of $\mathrm{pH} 7$, with variable amounts $(0.02 \%-1 \%)$ of soluble starch solution. The data was plotted according to Line-Weaver Burk plot as described [11].

2.9. Effect of Activators and Inhibitors on $\alpha$-Amylase Activity. The enzyme solutions were incubated for $10 \mathrm{~min}$ along with activators and inhibitors with the final concentration of $1 \mathrm{mM}$ at $55^{\circ} \mathrm{C}$ and then assayed in the presence of metal ions for $\alpha$-amylase activity. The various activators or inhibitors used were $\mathrm{HgCl}_{2}, \mathrm{CaCl}_{2}, \mathrm{CuSO}_{4}, \mathrm{MgCl}_{2}, \mathrm{ZnCl}_{2}, \mathrm{FeSO}_{4}, \mathrm{CaCl}_{2}$, $\mathrm{MnCl}_{2}, \mathrm{SDS}$, and EDTA.

2.10. SDS-Denaturing-Renaturing Polyacrylamide Gel Electrophoresis (SDS-DR-PAGE). Subunit molecular weight of $\alpha$ amylase was determined by subjecting crude and purified $\alpha$ amylase to $10 \%$ SDS-PAGE using Hoeffer small apparatus. After electrophoresis, the gel was incubated for $30 \mathrm{~min}$ in $100 \mathrm{mmol}$ potassium phosphate buffer $(\mathrm{pH}$ 7.5) containing $20 \%$ isopropanol for the removal of SDS. After removing SDS, the part of the gel containing different molecular weight markers was stained over night with Comassie $R-250$. The gel was destained with a solution of methanol, acetic acid and water with a ratio of $9: 2: 9$, respectively. The part of gel containing $\alpha$-amylase was transferred to potassium iodide solution (Gram's iodine) for activity staining [11].

2.11. Half-Life. Purified $\alpha$-amylase was redissolved in $100 \mathrm{mmol}$ phosphate buffer $(\mathrm{pH}$ 7) and assayed for thermostability. Optimum temperature of $\alpha$-amylase was determined in $100 \mathrm{mM}$ potassium phosphate buffer $(\mathrm{pH}$ $7.0)$ at selected temperatures $(50,5560,65,70,75,80,85$, 90,95 and $100^{\circ} \mathrm{C}$ ) of reaction system $[11,12]$. $\alpha$-Amylase was examined by incubating the enzyme in the above buffer, at certain temperatures $\left(50-90^{\circ} \mathrm{C}\right)$ and the enzyme samples were taken after $15,30,60,120$, and $180 \mathrm{~min}$ of incubation for the assay of enzyme activity.

2.12. Thermodynamics of Enzyme. Arrhenius relationship was used to calculate the activation energy $\left(E_{a}\right)$ required by the enzyme to hydrolyze starch as described earlier [11]. Thermal inactivation of the enzyme was determined by incubating the enzyme solutions in above buffer at a particular temperature. Aliquots were withdrawn at different times, cooled on ice, and assayed for enzyme activity at $55^{\circ} \mathrm{C}$ as described above. This procedure was repeated at different temperatures ranging from 45 to $100^{\circ} \mathrm{C}$. The data were fitted to first-order plots and analyzed. The first-order rate constants $\left(k_{d}\right)$ were determined by linear regression of $\ln (V)$ versus time of incubation $(t)$. The thermodynamic data were calculated by rearranging the Eyring absolute rate 
equation to study the overall thermodynamic parameters in the range $45-95^{\circ} \mathrm{C}$ :

$$
\begin{gathered}
\frac{K d=T \cdot k B / h e^{\Delta S^{*}}}{R} \frac{{ }_{\mathrm{e}} \Delta H^{*}}{R \cdot T}, \\
\ln \left(\frac{k_{d}}{T}\right)=\ln \left(\frac{k_{B}}{h}\right)+\frac{\Delta S^{*}}{R}-\frac{\Delta H^{*}}{R} \cdot \frac{1}{T},
\end{gathered}
$$

where $k_{d}, T, k_{B}, h, \Delta S^{*}, \Delta H^{*}$, and $R$ are specific reaction velocity, absolute temperature, Boltzmann constant, enthalpy of activation, and gas constant, respectively.

\section{Results and Discussion}

Various factors including particle size, inoculum density, moisture content, and enzyme extraction parameters were employed when wheat bran, maize starch, and maize bran were used. For comparison of data to make extrapolations, IUg-1 cells $\left(Y_{p / x}\right)$, IUg-1 substrate consumed $\left(Y_{p / s}\right)$, volumetric productivity's $\left(Q_{p}\right)$, and specific productivity $\left(q_{p}\right)$ of the enzyme have been presented in Tables 1(a) and 1(b). Wheat bran (15\%) proved to be the best carbon source to support maximum values of all kinetic parameters related to product formation. Maximum values of $\alpha$-amylase $Q_{p}$ (1302 IU L $\left.{ }^{-1 \mathrm{~h}}\right), Y_{p / x}$ (1333 $\mathrm{IU}^{\mathrm{g}-1}$ cells), $Y_{p / s}\left(22588 \mathrm{IU}^{\mathrm{g}-1}\right.$ substrate consumed), and $q_{p}\left(357 \mathrm{IUg}^{-1}\right.$ cells $\mathrm{h}^{-1}$ specific) were also improved (Table 1(a)). Growth yield coefficient $\left(Y_{x / s}\right)$, volumetric rate of substrate utilization $\left(Q_{s}\right)$, specific rate of substrate utilization $\left(q_{s}\right)$, specific growth rate $(\mu)$, and volumetric productivity of extracellular protein $\left(Q_{p e}\right)$ were also increased with $15 \%$ wheat bran (Table 1(b)).

The suitability of a particular substrate in a SSF process for the production of bacterial amylases appeared to be governed by the physicochemical requirement of the microorganisms used. The universal suitability of wheat bran may be due to the fact that it contains sufficient nutrients and is able to remain loose even in moist conditions, thus providing a large surface area. When compared to earlier studies in SSF [13], enzyme production was enhanced up to several in SSF and a 2.4-fold improvement in specific productivity was noted compared with submerged fermentation.

The novel aspect of the study was that spore forming indigenous Bacillus licheniformis RTPE1 strain produced maximum amount of extracellular $\alpha$-amylase when growth rate declined principally in the stationary phase (see representative Figure 1(a)), though maximum enzyme production was observed in the fermentation medium producing maximum amounts of biomass. In the earlier findings, mostly $\alpha$-amylase production was growth associated and highest enzyme activities were obtained in the exponential phase and even in the early stage of growth phase [5]. Very few findings revealed that the production of $\alpha$-amylase is nongrowth associated. Further enhancement in the catalytically active enzyme can be obtained by exploiting nitrogen sources and maintenance of proper aeration in the fermentation vessel.
3.1. SDS-Polyacrylamide Gel Electrophoresis of the Purified $\alpha$-Amylase of Indigenous Bacillus licheniformis RTPE1 Strain. Purified $\alpha$-amylase was subjected to SDS-PAGE as described in materials and methods. A single band of purified $\alpha$ amylase was observed in lane 1 (Figure 1(b)A). It was found that the molecular weight of $\alpha$-amylase was $112 \mathrm{kDa}$ and enzyme was active in situ and showed zone of clearance even in crude samples (Figure 1(b)B). Purified $\alpha$-amylase has been shown to be homogenous by SDS-PAGE. It has higher molecular weight than most of the $\alpha$-amylases from Bacillus $s p(40-140 \mathrm{kDa})[15]$.

3.2. Alkaline Nature of the Indigenous Bacillus lichenformis RT 7PE1 $\alpha$-Amylase. Studies of alkalophilic microorganisms had resulted in the discovery of extra-cellular enzymes that are characterized by maximum $\mathrm{pH}$ for activity and stability occurring on the alkaline side. Although various extracellular enzymes of alkalophilic microorganism have been described and only a few are alkaline amylases [16]. Maximum activity was observed at $\mathrm{pH} 9.0$ and $60^{\circ} \mathrm{C}$ (Figures 2(a) and $2(\mathrm{~b})$ ), which is very suitable for industrial use. In previous study, the effect of temperature and $\mathrm{pH}$ on the activity of $\alpha$ amylase, produced by Bacillus sp. KR-8104 in a solid state fermentation system, was optimized [17]. Comparing the results obtained from the optimization of crude $\alpha$-amylase activity in solid state and submerged fermentation systems revealed some differences in $\mathrm{pH}$ and temperature optima for maximizing the crude enzyme activity.

3.3. Effect of Metal Ions and Effectors on $\alpha$-Amylase Activity and Thermostability. The thermostability of purified enzyme was enhanced in the presence of $5 \mathrm{mM} \mathrm{Ca}^{2+}$ at $90^{\circ} \mathrm{C}$. The enzyme activity was strongly inhibited by $\mathrm{Hg}^{2+}, \mathrm{Pb}^{2+}, \mathrm{Zn}^{2+}$, $\mathrm{Cu}^{2+}$, EDTA, and SDS (Table 2) [12].

But in the presence of $5 \mathrm{mMCa}^{2+}$ enzyme retained $97 \%$ of its activity even after incubation of $180 \mathrm{~min}$ at $90^{\circ} \mathrm{C}$. In general high concentrations of both monovalent and divalent salts were inhibitory to the reaction. The inhibition depended upon the nature of the salt, either due to anionic strength effect or specific cation effect [10].

3.4. Liquefaction of Starch. Liquefaction of the $10 \%$ maize starch was done with purified $\alpha$-amylase (200 $\mathrm{IU} \mathrm{g}^{-1}$ starch) from indigenous Bacillus licheniformis RT7PE1 strain. The enzyme gave $100 \%$ dextrose equivalent (DE) values from $10 \%$ maize starch hydrolyzed completely after $360 \mathrm{~min}$ of incubation. Starch at 30\% (w/v) was not completely hydrolyzed to glucose (Figure 2(c)). High performance liquid chromatographic studies proved that the starch hydrolysis major product was maltose and oligosaccharides. The production of sugars from starch sources is an industry that exists in its present form due to the application of industrial enzymology to solve process related problems. As the industry matures, the demand for more efficient enzymes leading to higher quality products and lower production costs for the starch processing will increase [18]. 
TABle 1: (a) Comparative fermentation kinetic parameters* of B. licheniformis RTPE1 for $\alpha$-amylase formation following growth on different substrates in solid state fermentation under optimized fermentation conditions. (b) Comparative fermentation kinetic parameters of $B$. licheniformis RTPE1 for $\alpha$-amylase formation following growth on different substrates in solid state fermentation under optimized fermentation conditions.

(a)

\begin{tabular}{lcccc}
\hline Carbon source & $\begin{array}{c}Q_{p} \\
\mathrm{IU} \mathrm{L}^{-1} \mathrm{~h}^{-1}\end{array}$ & $\begin{array}{c}Y_{p / s} \\
\mathrm{IUg}\end{array}$ & $\begin{array}{c}Y_{p / X} \\
\mathrm{IUg}^{-1} \\
\text { cells }\end{array}$ & $\begin{array}{c}q_{p} \\
\text { substrate utilized }\end{array}$ \\
\hline $5 \%$ wheat bran & $535 \pm 25$ & $1500 \pm 10$ & $11904 \pm 25$ & $357 \pm 25$ \\
$10 \%$ wheat bran & $1262 \pm 35$ & $1550 \pm 12$ & $19375 \pm 30$ & $775 \pm 28$ \\
$15 \%$ wheat bran & $1302 \pm 29$ & $1333 \pm 15$ & $22588 \pm 35$ & $1242 \pm 30$ \\
$10 \%$ maize starch & $427 \pm 41$ & $1260 \pm 14$ & $10500 \pm 26$ & $315 \pm 21$ \\
$5 \%$ maize bran & $867 \pm 30$ & $1420 \pm 12$ & $18933 \pm 29$ & $719 \pm 12$ \\
$10 \%$ maize bran & $990 \pm 45$ & $1100 \pm 13$ & $16500 \pm 31$ & $858 \pm 23$ \\
$15 \%$ maize bran & $851 \pm 48$ & $1450 \pm 14$ & $17682 \pm 32$ & $725 \pm 25$ \\
\hline
\end{tabular}

Each value is a mean of three replicates. ( \pm ) stands for standard deviation among replicates. ${ }^{*} Q_{p}=\mathrm{IU} 1^{-1} \mathrm{~h}^{-1}, Y_{p / s}=\mathrm{IU} \mathrm{g}^{-1}$ substrate utilized, $Y_{p / X}=\mathrm{IU} \mathrm{g}^{-1}$ cell, and $q_{p}=$ specific productivity $=\mathrm{IU} \mathrm{g}^{-1}$ cells $\mathrm{h}^{-1}$ and were determined as described previously [14].

(b)

\begin{tabular}{lccccr}
\hline Carbon source & $\begin{array}{c}\text { Biomass g } \\
\text { g DW/Lh }\end{array}$ & $\begin{array}{c}Y_{x / s} \\
\mathrm{~g} / \mathrm{g}\end{array}$ & $\begin{array}{c}\mathrm{Q}_{s} \\
\mathrm{~g} / \mathrm{L} / \mathrm{h}\end{array}$ & $\begin{array}{c}q_{s} \\
\mathrm{~g} / \mathrm{gh}\end{array}$ & $\begin{array}{c}\mathrm{Q}^{2} \\
\left(\mathrm{~h}^{-1}\right)\end{array}$ \\
\hline $5 \%$ wheat bran & 0.079 & 0.126 & 0.281 & 0.238 & 0.0300 \\
$10 \%$ wheat bran & 0.084 & 0.080 & 0.351 & 0.560 & 0.040 \\
$15 \%$ wheat bran & 0.095 & 0.062 & 0.554 & 0.887 & 0.055 \\
$10 \%$ maize starch & 0.053 & 0.082 & 0.600 & 0.500 & 0.271 \\
$5 \%$ maize bran & 0.052 & 0.120 & 0.285 & 0.250 & 0.300 \\
$10 \%$ maize bran & 0.063 & 0.075 & 0.487 & 0.506 & 0.030 \\
$15 \%$ maize bran & 0.0635 & 0.056 & 0.650 & 0.092 & 0.038 \\
\hline
\end{tabular}

$Y_{x / s}$ : growth yield coefficient, $Q_{s}$ : volumetric rate of substrate utilization, $q_{s}:$ specific rate of substrate utilization, $\mu$ : specific growth rate, and $\mathrm{QP} e$ : volumetric productivity of extracellular protein. Each value is a mean of three replicates. ( \pm ) stands for standard deviation among replicates.

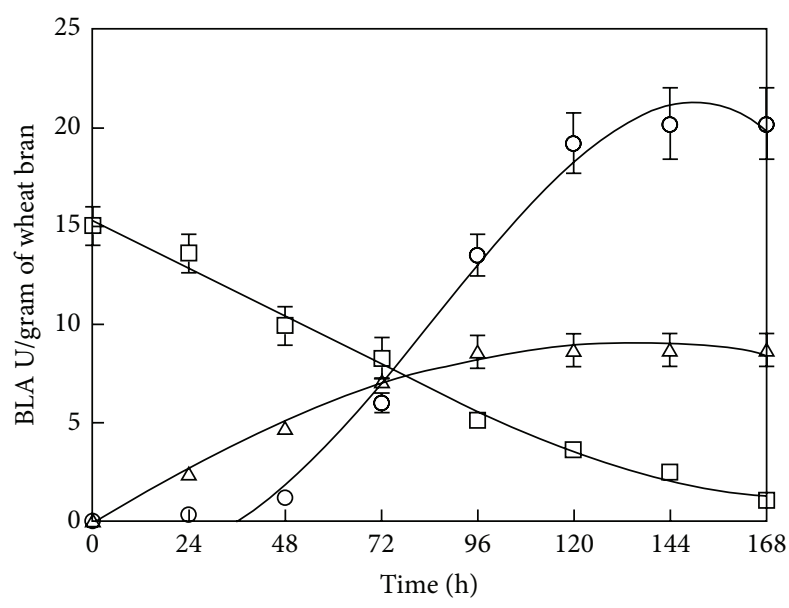

(a)

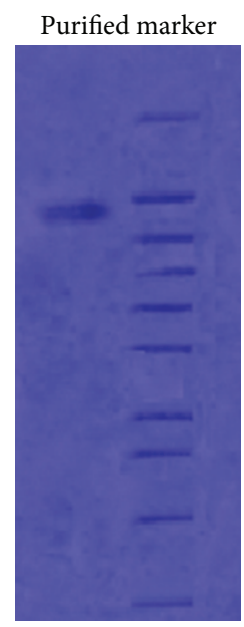

(A)

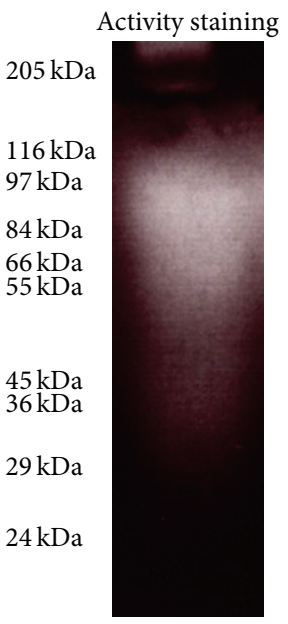

(B)

(b)

FIGURE 1: (a) Kinetics of alpha-amylase production in solid state fermentation using wheat bran. The initial pH of the medium was 7.0 and temperature $37^{\circ} \mathrm{C}$. $\mathrm{O}$ : alpha-amylase, $\Delta: X$ (cell mass), and $\square: S$ (substrate) present in the fermentation medium. Error bars show standard deviation among three replicates. (b) Purification profile of enzyme on SDS-PAGE: A, lane 1: purified enzyme; lane 2: molecular weight markers; B, lane 1: activity staining of purified enzyme. 


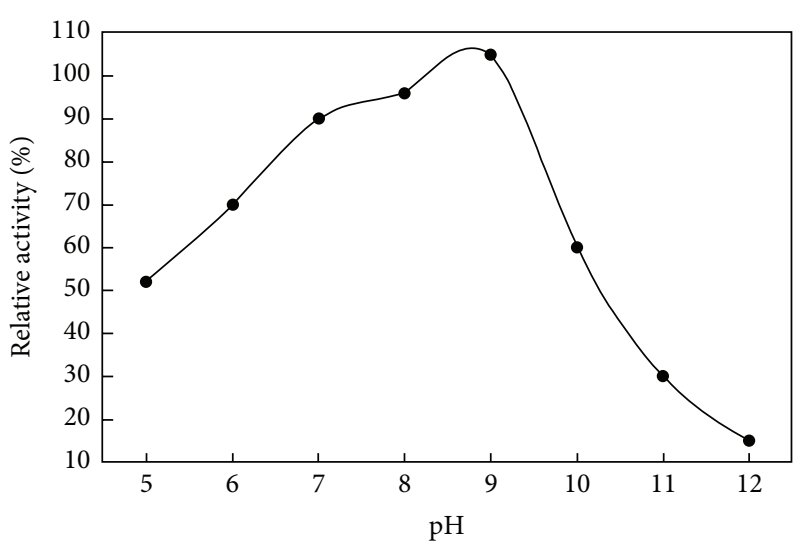

(a)

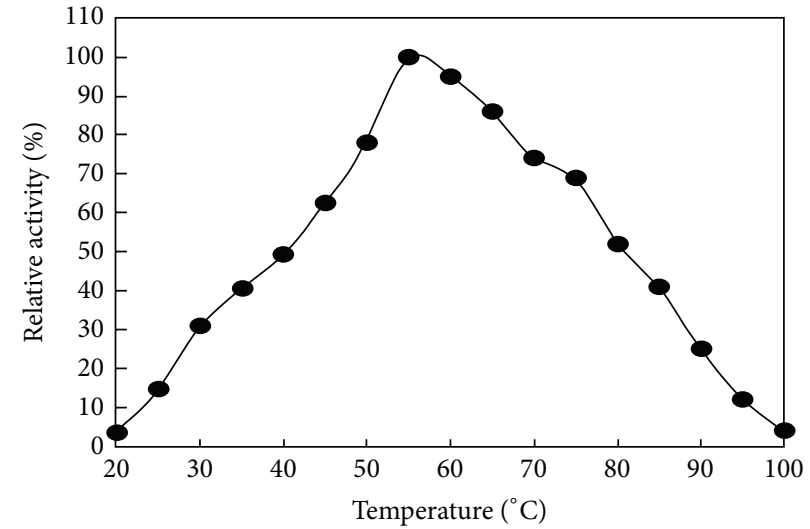

(b)

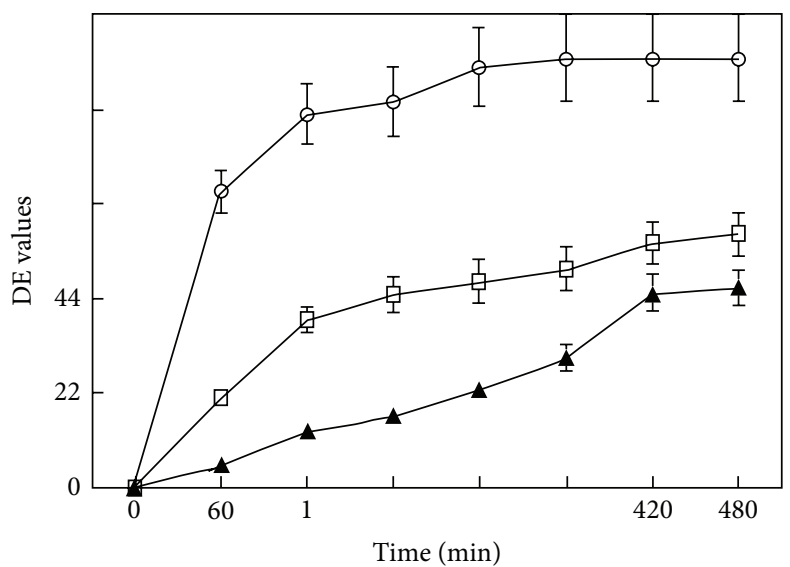

(c)

FIGURE 2: (a) Effect of pH on enzyme activity, (b) effect of temperature on enzyme activity, and (c) liquefaction of maize starch used at different concentrations: $\Delta$ 10\% maize starch, $\square 20 \%$ maize starch, and $\bigcirc 30 \%$ maize starch. Enzyme was used $200 \mathrm{IU}$ per g substrate at $55^{\circ} \mathrm{C}$.

TABLE 2: Effect of metal ions (used at $5 \mathrm{mM}$ ) on enzyme activity.

\begin{tabular}{lc}
\hline Metal ions & \% Relative activity \\
\hline Control & $100 \pm 3$ \\
$\mathrm{CaCl}_{2} \cdot 2 \mathrm{H}_{2} \mathrm{O}$ & $115 \pm 4$ \\
$\mathrm{CoCl}_{2} \cdot 6 \mathrm{H}_{2} \mathrm{O}$ & $23 \pm 1$ \\
$\mathrm{FeSO}_{4} \cdot 5 \mathrm{H}_{2} \mathrm{O}$ & $20 \pm 3$ \\
$\mathrm{HgCI}_{2}$ & $0 \pm 0$ \\
$\mathrm{KCI}$ & $67 \pm 3$ \\
$\mathrm{CuSO}_{4}$ & $0 \pm 0$ \\
$\mathrm{MgSO}_{4}$ & $97 \pm 4$ \\
EDTA & $30 \pm 2$ \\
SDS & $20 \pm 2$ \\
\hline
\end{tabular}

Each value is a mean of three readings; \pm : stands for standard deviation among replicates.

3.5. Effect of Starch Concentration on Catalytic Activity. The reaction was dependent on the amount of starch present in the reaction mixture. A Line-weaver Burk plot (Figure 3(a)) of the data reveals a $K_{m}$ of $3.4 \mathrm{mg}$ starch $\mathrm{mL}^{-1}$. The $V_{\max }$ is $19.5 \mu \mathrm{mol} \mathrm{min}^{-1}$. So the amylase exhibited MichaelisMenten-type kinetics. The kinetic parameters of $\alpha$-amylase

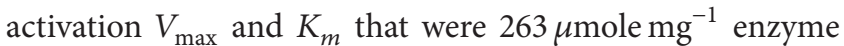
$\mathrm{min}^{-1}$ and $0.97 \mathrm{mg} / \mathrm{mL}$, respectively, were reported from thermopile Bacillus sphaericus [14]. The $V_{\max }$ and $K_{m}$ values for soluble starch was found to be $4.11 \mathrm{mg} / \mathrm{min}$ and $3.076 \mathrm{mg}$, respectively, for $\alpha$-amylase isolated from B. amyloliquefaciens previously reported by Gangadharan et al. [19].

3.6. Effect of Temperature on $\alpha$-Amylase Activity and Stability. Stability of the enzyme at higher temperature up to $100^{\circ} \mathrm{C}$ was examined, and the enzyme was optimally active at $55-60^{\circ} \mathrm{C}$ $\left(130 \mathrm{IU} \mathrm{mL}^{-1}\right.$ ) (Figure $3(\mathrm{~b})$ ) and showed $14 \%$ relative enzyme activity at $100^{\circ} \mathrm{C}$. The temperature-dependent properties of this enzyme show some similarity to Bacillus licheniformis $\alpha$ amylase (BLA) produced by recombinant $E$. coli which was active over a temperature range of $50-80^{\circ} \mathrm{C}$ and had optimal activity at $60^{\circ} \mathrm{C}[20]$.

3.7. Half-Life and Activation Energy. The protein midpoint inactivation temperature $\left(T_{m}\right)$, activation energy, conformational stability at elevated temperatures, activation parameters for catalytic activity, transition state formation energy, stability of the native state ensemble are potential indices 


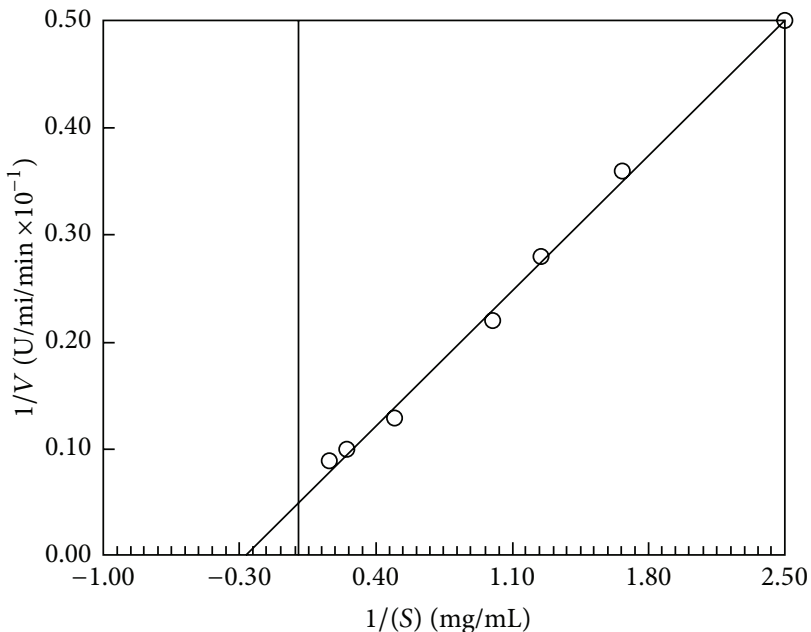

(a)

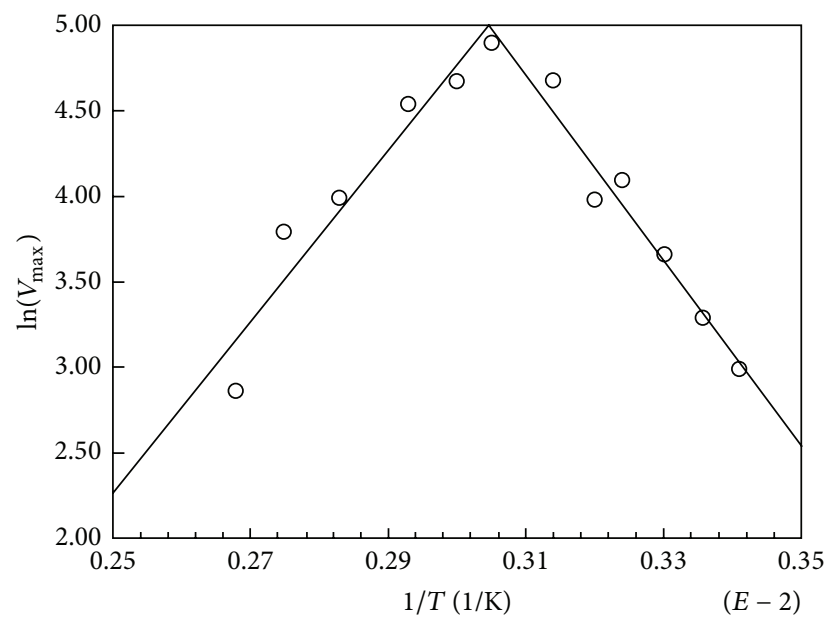

(c)

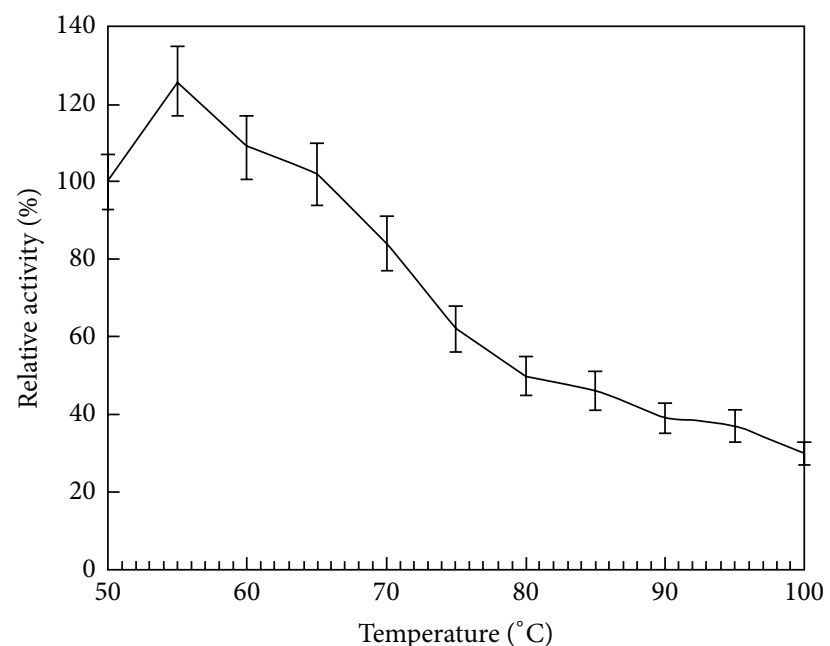

(b)

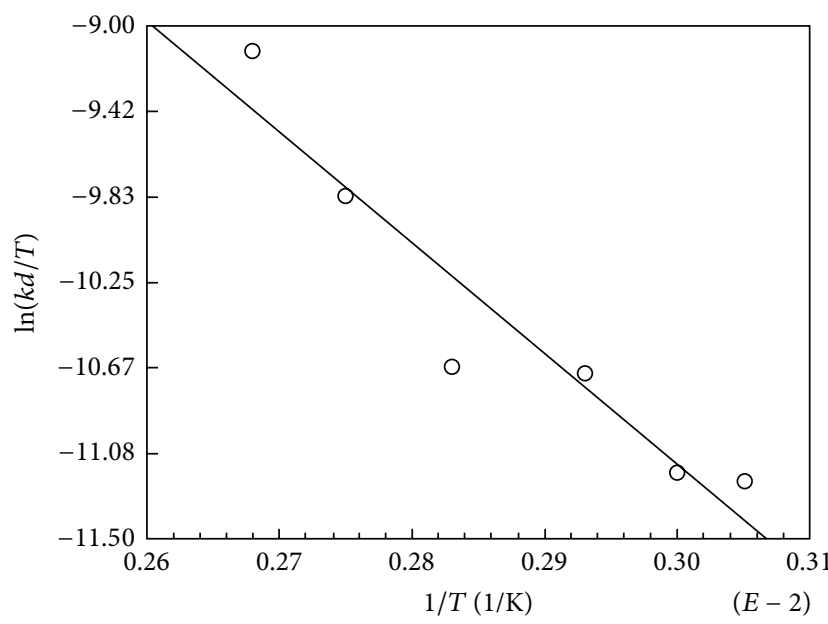

(d)

Figure 3: (a) Line weaver-Burk plot for calculation of $K_{m}$ and $V_{\max }$ of enzyme. (b) Determination of protein midpoint $\left(T_{m}\right)$ for denaturation. Relative activity at each temperature was calculated as described in Materials and Methods and plotted against temperatures. $T_{m}$ is that temperature at which held of enzyme is defolded. (c) Arrhenius plots for calculation of activation energy. (d) Arrhenius plots for calculation of activation enthalpy and entropy of alpha-amylase inactivation.

for thermostable biocatalysts. The $T_{m}$ value was $89^{\circ} \mathrm{C}$ (Table 3(a)). For Bacillus licheniformis amylase (BLA) at $\mathrm{pH}$ 7.0, the $T_{m}$ of $103^{\circ} \mathrm{C}$ was obtained [20].

Activation energy for catalysis of soluble starch was $45.2 \mathrm{~kJ} \mathrm{~mol}^{-1}$ (Table 3(a)). The activation energy for $B$. licheniformis CUMC305 enzyme was calculated as $5.1 \times$ $105 \mathrm{~J} / \mathrm{mol}$. The investigated most thermostable $\alpha$-amylases from Bacillus licheniformis enzymes exhibit activation energies $\left(E_{a}\right)$ between 208 and $364 \mathrm{kJmol}^{-1}$ and pronounced differences in the corresponding unfolding rates. After the inflexion in temperature (Figure 3(c)), the enzyme becomes denatured and shows less activity towards conversion of substrate into product with decrease in activation energy $\left(41.2 \mathrm{~kJ} \mathrm{~mol}^{-1}\right)$ which infers thermostability of the test enzyme [21].

3.8. Kinetics of Starch Hydrolysis. The ratio $k_{\text {cat }} / K_{m}$ often referred to as the "specificity constant" is a useful index for comparing the relative rates of enzyme acting on alternative, competing substrates. In present studies, $k_{\text {cat }}$ is $2395 / \mathrm{min}$ and the specificity constant $k_{\text {cat }} / K_{m}$ of this enzyme is 7068 (Table 3(a)). The reported $k_{\text {cat }}$ for $\alpha$-amylase from B. amyloliquefaciens is $2.26 \times 10^{3} \mathrm{~s}^{-1}[22,23]$. This could be due to the ionized state of the carboxyl whose charges are positive ones and the substrate (full chair conformation of sugar residue) binds more strongly to the active site than the transition state of the substrate (sofa form of the positively charged oxocarbonium ion). It was found that the entropy of denaturation $\left(\Delta S^{*}\right)$ of alpha-amylase at $60^{\circ} \mathrm{C}$ was significantly decreased as compared with other enzymes indicating altered and more compact conformation for this enzyme. This happens due to the increase in the hydrophobicity around active site, as a result of local conformational change due to substrate (starch) binding and is a common phenomenon.

3.9. Thermodynamics of Starch Hydrolysis by Alpha-Amylase. The organism-derived enzyme requires less free energy $\left(\Delta G_{E-T}^{*}\right)$ to form the transition state than that required by 
other organisms (Table 3(a)). Similarly, enzyme releases the higher amount of transition state binding energy $\left(\Delta G_{E-S}^{*}\right)$ as compared with those of others (Table 3(a)), signifying that the high catalytic efficiency of alpha-amylase is due to the transition state stabilization. Accordingly, this enzyme showed highest enzyme-substrate destabilization $\left(\Delta G_{E-S}^{*}\right)$, whereas other enzymes showed least enzyme-substrate destabilization energy (Table $3(\mathrm{a})$ ). The activation energy $\left(E_{a}\right)$ profiles of the enzyme show that this alpha-amylase has lower $E_{a}$ values up to $90^{\circ} \mathrm{C}$.

These studies provided insight into improvement in enzyme production and the process of stabilization by this strain. The culture had altered the values of both entropy and enthalpy of activation for irreversible inactivation of enzyme as observed for thermostabilized enzymes [24]. Actually thermal inactivation occurs in two steps as follows:

$$
N \longleftrightarrow U \longrightarrow I
$$

where $N$ is the native, $U$ is the unfolded enzyme which could be reversibly refolded upon cooling, and $I$ is the inactivated enzyme formed after prolonged exposure to heat and therefore can not be recovered on cooling.

The thermal denaturation of enzymes is accompanied by the disruption of noncovalent linkages, including hydrophobic interactions, with concomitant increase in the enthalpy of activation [24]. The opening up of the enzyme structure is accompanied by an increase in the disorder, randomness or entropy of activation. The values of thermodynamic parameters were calculated from Figure 3(d). The enzyme had $44.8 \mathrm{~kJ} \mathrm{~mol}^{-1}$ and $-155.6 \mathrm{~J} \cdot \mathrm{mol}^{-1} \mathrm{~K}^{-1} \Delta H^{*}$ (enthalpy of deactivation) and $\Delta S^{*}$ (entropy of deactivation) values respectively. The values of $\Delta S^{*}$ and $\Delta H^{*}$ of $\beta$-glucosidase from a thermophilic culture of Aspergillus wentii [24] were $125 \mathrm{~kJ} \mathrm{~mol}^{-1}$ and $65 \mathrm{~J} \cdot \mathrm{mol}^{-1} \mathrm{~K}^{-1}$, respectively. The values of BLA here are markedly lower, therefore, up to $95^{\circ} \mathrm{C}$, the enzyme was reasonably thermostable. These values are also significantly lower than those reported on thermostable mutant of Aspergillus awamori glucoamylase [24]. When enthalpy and entropy values for inactivation were calculated at each temperature, $\Delta S^{*}$ had again negative values (Table 3(b)). This suggested that there was negligible disorderness as was that of $\beta$-glucosidase from $A$. wentii or the transition state of $\alpha$-amylase from Bacillus licheniformis was found to be more ordered as revealed by its negative $\Delta S^{*}\left(-150 \mathrm{~J} \mathrm{~mol}^{-1} \mathrm{~K}^{-1}\right)$ at high temperature of $80^{\circ} \mathrm{C}$ [25].

\section{Conclusion}

From the present study it is apparent that production of alpha amylase production by solid state fermentation from $15 \%$ wheat bran was higher as compared to $15 \%$ gram bran by newly isolated Bacillus licheniformis RT7PE1 strain. The wheat bran was best and cheap source for production of alpha amylase. The production of enzyme in submerged fermentation is expensive as compared to solid state fermentation. The contents of synthetic media are very expensive and
TABLE 3: (a) Kinetic and thermodynamic properties of $\alpha$-amylase from Bacillus licheniformis RTPE1 strain. (b) Kinetic and thermodynamic parameters for irreversible thermal inactivation of $\alpha$-amylase from B. licheniformis RTPE1.

(a)

\begin{tabular}{lc}
\hline Parameters & Values \\
\hline$k_{\text {cat }}\left(\mathrm{min}^{-1}\right)^{\mathrm{a}}$ & 2395 \\
$K_{m}(\% \mathrm{w} / \mathrm{v})$ & 0.34 \\
$k_{\text {cat }} / K_{m}$ & 7043 \\
$\left.E_{a}(\mathrm{~kJ} \mathrm{~mol})^{-1}\right)^{\mathrm{b}}$ & 45.2 \\
$M_{r}(\mathrm{kDa})$ & 124 \\
$\mathrm{pH}$ optimum & 9.5 \\
Temperature optima & 55 \\
$T_{m}(\mathrm{Midpoint} \mathrm{Temp})$ & 89 \\
$\Delta G^{*}(\mathrm{~kJ} \mathrm{~mol})^{-1}$ & -164.8 \\
$\Delta H^{*}\left(\mathrm{~kJ} \mathrm{~mol}^{-1}\right)^{\mathrm{f}}$ & 44.8 \\
$\Delta S^{*}\left(\mathrm{Jmol}^{-1} \mathrm{~K}^{-1}\right)^{\mathrm{g}}$ & -155.6 \\
$\Delta G_{E-T}^{*}\left(\mathrm{~kJ} \mathrm{~mol}^{-1}\right)^{\mathrm{h}}$ & -30.3 \\
$\Delta S_{E-S}^{*}\left(\mathrm{~kJ} \mathrm{~mol}^{-1}\right)^{\mathrm{I}}$ & -2.86 \\
\hline
\end{tabular}

${ }^{\text {a Turnover number }}\left(k_{\text {cat }}\right)=V_{\max } /[e]$, where $e$ is $\alpha$-amylase concentration $(0.00806 \mu \mathrm{mol})$. NA: not available.

${ }^{\mathrm{b}}$ Activation energies $\left(E_{a}\right)$ determined as described previously [11].

${ }^{\mathrm{e}} \Delta G^{*}$ (activation free energy of $\alpha$-amylase hydrolysis) $=-R T \cdot \ln$ $\left(k_{\text {cat }} \cdot h\right) /\left(K_{B} \cdot T\right)$, where $h$ is planck constant $\left(6.63 \times 10^{-34} \mathrm{Js}\right), K_{B}$ is boltzman constant $\left(1.38 \times 10^{-23} \mathrm{JK}^{-1}\right)$, and $R$ is gas constant $\left(8.314 \mathrm{JK}^{-1} \mathrm{~mol}^{-1}\right)$.

${ }^{\mathrm{f}} \Delta H$ (activation enthalpy of starch hydrolysis) $E_{a}-R T$.

${ }^{\mathrm{g}} \Delta S$ (activation entropy of starch hydrolysis) $=\left(\Delta H^{*}-\Delta G^{*}\right) / T$.

${ }^{\mathrm{i}} \Delta G_{E-T}$ (free energy of transition state binding) $=-R T \ln k_{\text {cat }} / K_{m}$.

${ }^{\mathrm{I}} \Delta S_{E-S}$ (free energy of substrate binding) $=-R T \ln K_{a}$, where $K_{a}=1 / K_{m}$.

(b)

\begin{tabular}{cccccc}
\hline$T$ & $\begin{array}{c}K_{d} \\
10^{-3} \mathrm{~h}^{-1}\end{array}$ & $\begin{array}{c}t_{1 / 2} \\
(\mathrm{~h})\end{array}$ & $\begin{array}{c}\Delta H^{*} \\
\mathrm{~kJ} \mathrm{~mol}^{-1}\end{array}$ & $\begin{array}{c}\Delta G^{*} \\
\mathrm{~kJ} \mathrm{~mol}^{-1}\end{array}$ & $\begin{array}{c}\Delta S^{*} \\
\mathrm{~J} \mathrm{~mol}^{-1} \mathrm{~K}^{-1}\end{array}$ \\
\hline 323 & 4.4 & 158 & 42.51 & 115.76 & -226 \\
328 & 4.7 & 147 & 42.47 & 117.53 & -229 \\
333 & 6.8 & 102 & 42.43 & 118.29 & -230 \\
343 & 7.8 & 89 & 42.35 & 121.59 & -231 \\
353 & 8.3 & 83 & 42.27 & 125.04 & -234 \\
363 & 18.0 & 38 & 42.18 & 126.33 & -240 \\
368 & 41.0 & 17 & 42.18 & 127.12 & -231 \\
\hline
\end{tabular}

${ }^{+} K_{d}$ (first-order rate constant for inactivation) was calculated from relationship, $K_{d} \cdot t=\ln V$, where $t$ is time of incubation and $V$ is the reaction velocity. $t_{1 / 2}$ : half-life of enzyme.

$\Delta H^{*}\left(\mathrm{~kJ} \mathrm{~mol}^{-1}\right)=E_{a}\left(45.2 \mathrm{~kJ} \mathrm{~mol}^{-1}\right)-R T$, where $E_{a}$ is activation energy. $\Delta G^{*}\left(\mathrm{~kJ} \mathrm{~mol}^{-1}\right)=-R T \ln \left(k_{d} \cdot h\right) /\left(k_{B} \cdot T\right)$

$\Delta S^{*}$ is entropy of irreversible inactivation and was calculated from $\Delta S^{*}=$ $\Delta H^{*}-\Delta G^{*} / T$.

these contents might be replaced with more economically agricultural waste material for the reduction of cost of the medium. The use of agricultural wastes makes solid state fermentation an attractive alternative method. There is on going interest in the isolation of new bacterial strains to produce amylases for new industrial applications, such as alkaline amylases for the detergent industry. This $\alpha$-amylase can be used as a good model protein for investigation of the 
molecular basis of alkalophilicity of moderately thermostable alkaline enzymes.

\section{Conflict of Interests}

The authors declare that there is no conflict of interests regarding the publication of this paper.

\section{Acknowledgments}

The work described is part of the M.Phil, research of Ms. Shazia Khaliq. The authors do not have any conflict of interest for financial, commercial, and professional to publish this paper, supported by PAEC. The technical assistance of Mr. Khalid Yaqoob is appreciated.

\section{References}

[1] P. Nigam and D. Singh, "Enzyme and microbial systems involved in starch processing," Enzyme and Microbial Technology, vol. 17, no. 9, pp. 770-778, 1995.

[2] Z. Baysal, F. Uyar, M. Doğru, and H. Alkan, "Production of extracellular alkaline alpha-amylase by solid state fermentation with a newly isolated Bacillus sp," Preparative Biochemistry \& Biotechnology, vol. 38, no. 2, pp. 184-190, 2008.

[3] R. R. Singhania, A. K. Patel, C. R. Soccol, and A. Pandey, "Recent advances in solid-state fermentation," Biochemical Engineering Journal, vol. 44, no. 1, pp. 13-18, 2009.

[4] M. J. Maarel, V. B. Vander, J. C. Uitdehaag, H. Leemhuis, and L. Dijkhuizen, "Properties and applications of starch-converting enzymes of the $\alpha$-amylase family," Journal of Biotechnology, vol. 94, no. 2, pp. 137-155, 2002.

[5] S. Sivaramakrishnan, D. Gangadharan, K. M. Nampoothiri, C. R. Soccol, and A. Pandey, " $\alpha$-Amylases from microbial sources-an overview on recent developments," Food Technology and Biotechnology, vol. 44, no. 2, pp. 173-184, 2006.

[6] M. Hashemia, S. M. Mousavib, S. H. Razavi, and S. A. Shojaosadati, "Comparison of submerged and solid state fermentation systems effects on the catalytic activity of Bacillus sp. KR-8104 $\alpha$-amylase at different $\mathrm{pH}$ and temperatures," Industrial Crops and Products, vol. 43, pp. 661-667, 2013.

[7] P. Bernfield, "Amylases $\alpha$ and $\beta$," in Methods in Enzymology, S. Colowick and N. Keplan, Eds., pp. 149-158, Academic Press, New York, NY, USA, 1951.

[8] M. M. Bradford, "A rapid and sensitive method for the quantitation of microgram quantities of protein utilizing the principle of protein dye binding," Analytical Biochemistry, vol. 72, no. 1-2, pp. 248-254, 1976.

[9] X.-Z. Zhang, S. Xie, X. Wu, F. Jin, and X. Li, "Purification and characterization of thermostable $\alpha$-amylase II from Bacillus spJF2 strain," Enzyme and Microbial Technology, vol. 16, no. 11, pp. 985-990, 1994.

[10] M. Hashemi, S. H. Razavi, S. A. Shojaosadati, and S. M. Mousavi, "Evaluation of Ca-independent $\alpha$-amylase production by Bacillus sp. KR-8104 in submerged and solid state fermentation systems," Iranian Journal of Biotechnology, vol. 9, no. 3, pp. 188-196, 2011.

[11] S. Aiba, A. E. Humphrey, and N. F. Millis, Biochemical Engineering Fundamentals, McGraw Hill, New York, NY, USA, 2nd edition, 1973.
[12] L.-L. Lin, C.-C. Chyau, and W.-H. Hsu, "Production and properties of a raw-starch-degrading amylase from the thermophilic and alkaliphilic Bacillus sp. TS-23," Biotechnology and Applied Biochemistry, vol. 28, no. 1, pp. 61-68, 1998.

[13] H. Anto, U. Trivedi, and K. Patel, "Alpha amylase production by Bacillus cereus MTCC 1305 using solid-state fermentation," Food Technology and Biotechnology, vol. 44, no. 2, pp. 241-245, 2006.

[14] Z. Al-Qodah, H. Daghstani, P. Geopel, and W. Lafi, "Determination of kinetic parameters of $\alpha$-amylase producing thermophile Bacillus sphaericus," African Journal of Biotechnology, vol. 6, no. 6, pp. 699-706, 2007.

[15] D. J. Bolton, C. T. Kelly, and W. M. Fogarty, "Purification and characterization of the $\alpha$-amylase of Bacillus flavothermus," Enzyme and Microbial Technology, vol. 20, no. 5, pp. 340-343, 1997.

[16] S. Ito, T. K. Kobayashi, K. Ara, K. Ozaki, S. Kawai, and Y. Hatada, "Alkaline detergent enzymes from alkaliphiles: enzymatic properties, genetics, and structures," Extremophiles, vol. 2, no. 3, pp. 185-190, 1998.

[17] M. Hashemi, S. H. Razavi, S. A. Shojaosadati, S. M. Mousavi, K. Khajeh, and M. Safari, "Development of a solid-state fermentation process for production of an alpha amylase with potentially interesting properties," Journal of Bioscience and Bioengineering, vol. 110, no. 3, pp. 333-337, 2010.

[18] M. R. Swain and R. C. Ray, "Alpha-amylase production by Bacillus subtilis CM3 in solid state fermentation using cassava fibrous residue," Journal of Basic Microbiology, vol. 47, no. 5, pp. 417-425, 2007.

[19] D. Gangadharan, K. M. Nampoothiri, S. Sivaramakrishnan, and A. Pandey, "Biochemical characterization of raw-starchdigesting alpha amylase purified from Bacillus amyloliquefacien," Applied Biochemistry and Biotechnology, vol. 158, no. 3, pp. 653-662, 2009.

[20] N. Declerck, M. Machius, P. Joyet, G. Wiegand, R. Huber, and C. Gaillardin, "Hyperthermostabilization of Bacillus licheniformis $\alpha$-amylase and modulation of its stability over a 50॰C temperature range," Protein Engineering, vol. 16, no. 4, pp. 287-293, 2003.

[21] S. D’Amico, J.-C. Marx, C. Gerday, and G. Feller, "Activitystability relationships in extremophilic enzymes," Journal of Biological Chemistry, vol. 278, no. 10, pp. 7891-7896, 2003.

[22] A. Tanaka and E. Hoshino, "Secondary calcium-binding parameter of Bacillus amyloliquefaciens $\alpha$-amylase obtained from inhibition kinetics," Journal of Bioscience and Bioengineering, vol. 96, no. 3, pp. 262-268, 2003.

[23] R. M. Daniel, "The upper limits of enzyme thermal stability," Enzyme and Microbial Technology, vol. 19, no. 1, pp. 74-79, 1996.

[24] H. Chen, U. Bakir, P. J. Reilly, and C. Ford, "Increased thermostability of Asn182 $\rightarrow$ Ala mutant Aspergillus awamori glucoamylase," Biotechnology and Bioengineering, vol. 43, no. 1, pp. 101-105, 1994.

[25] H. Ohnishi, H. Sakai, Y. Nosoh, and T. Sekiguchi, "Protein engineering for thermotability," TIBTECH, vol. 19, pp. 16-20, 1996. 

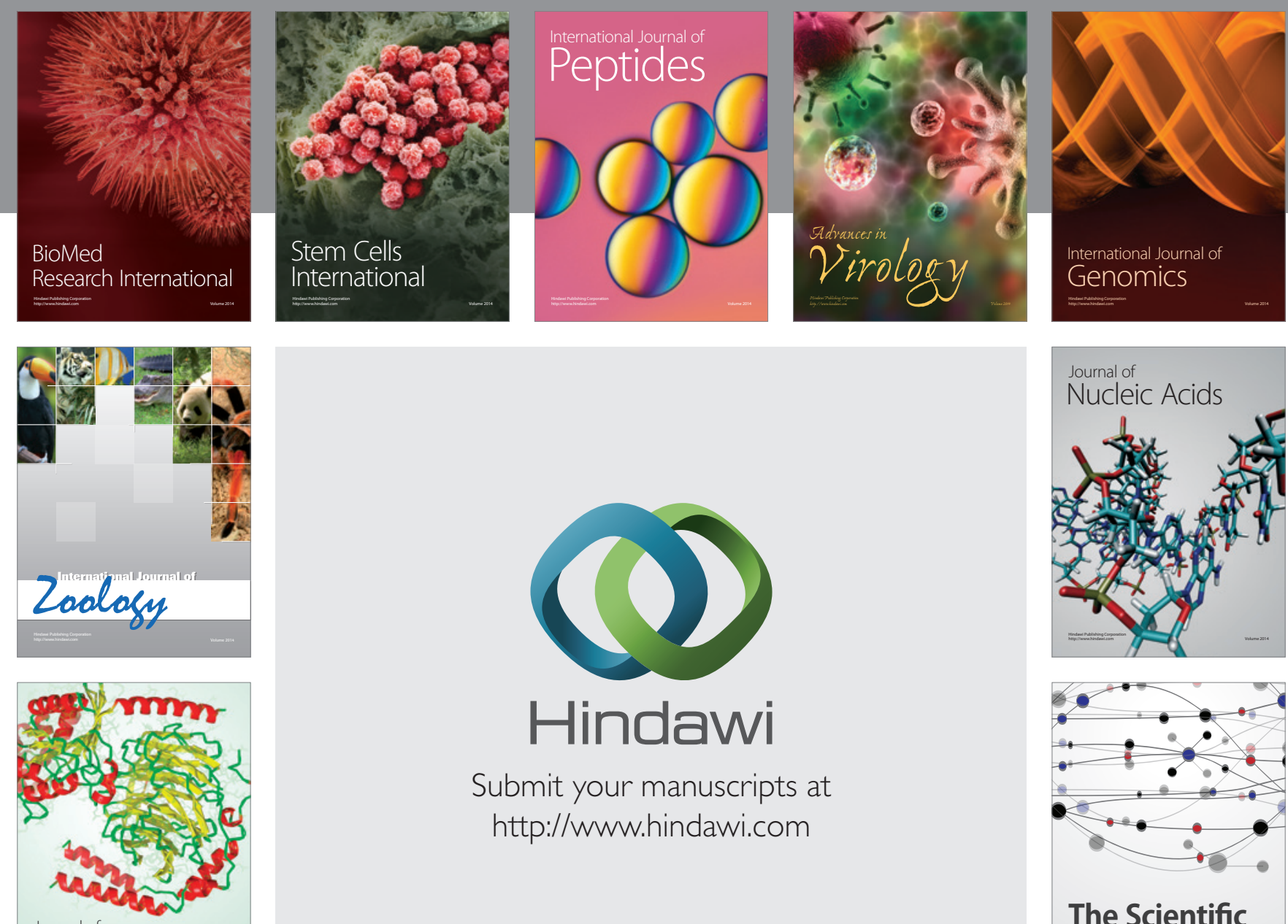

Submit your manuscripts at

http://www.hindawi.com

Journal of
Signal Transduction
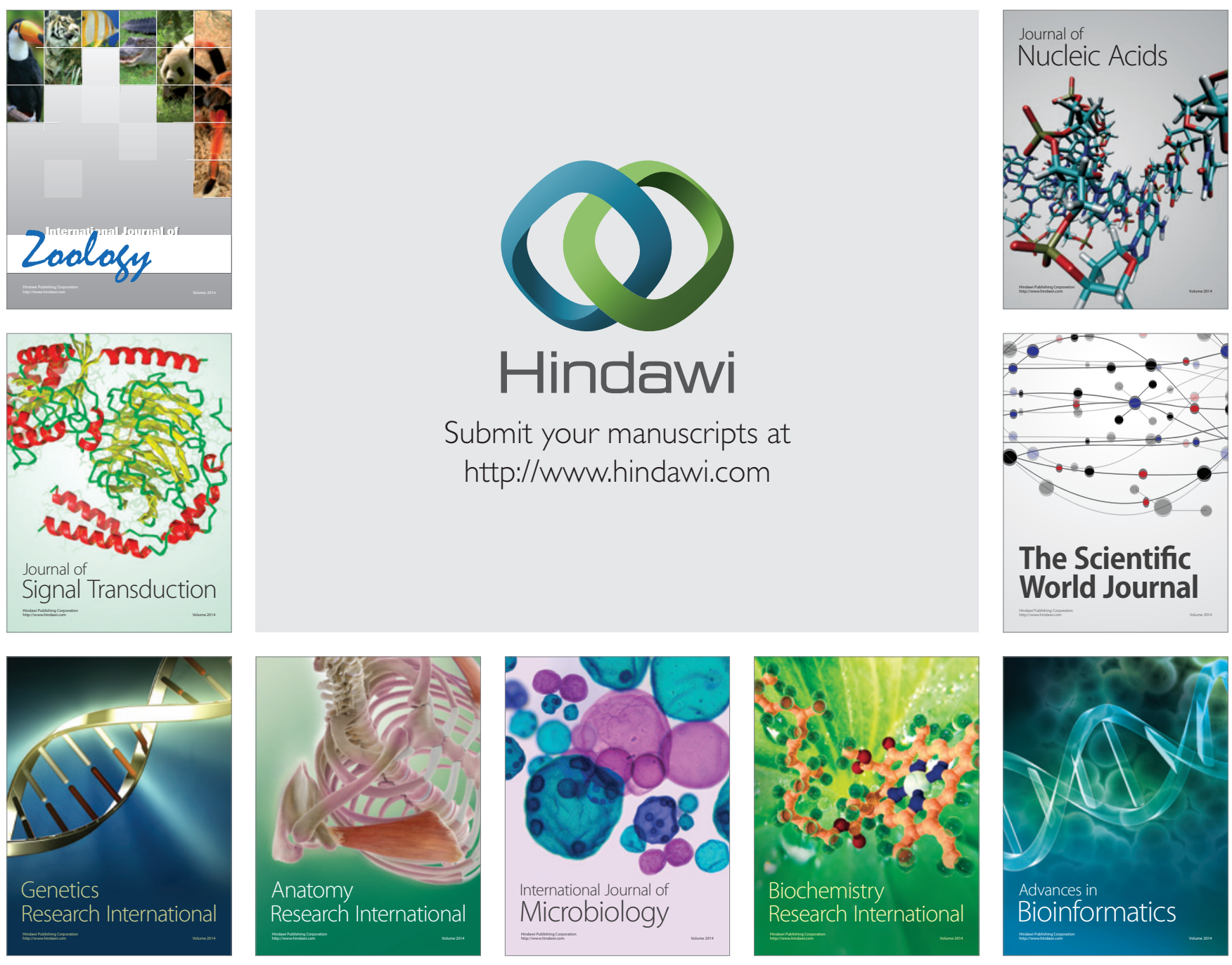

The Scientific World Journal
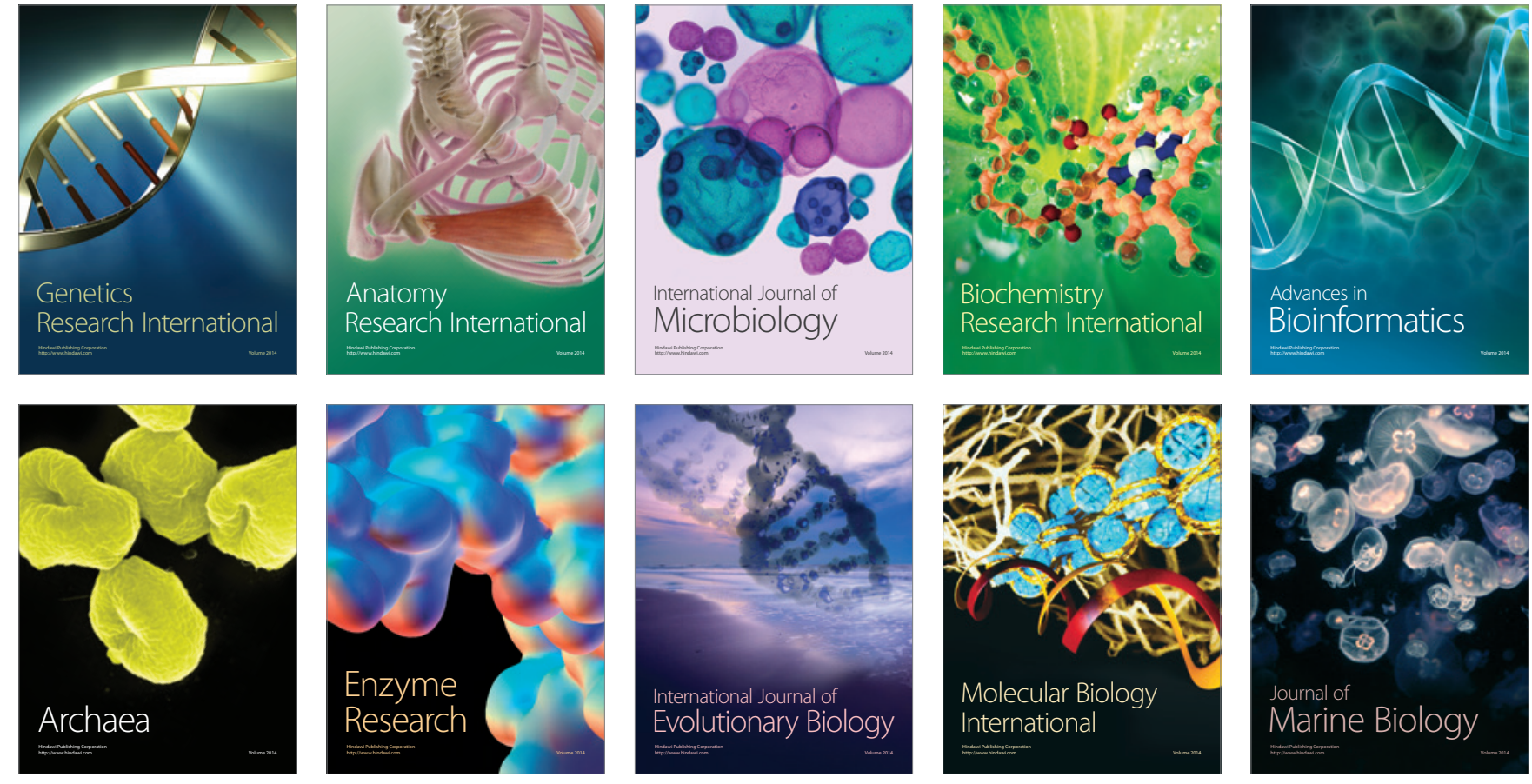